\title{
Isolation of MRSA from Drinking water Supplies in Al-Anbar Province, Iraq
}

\author{
Shirin Yasin Bdewi ${ }^{1}$, Mohammad Hamid Kareem², Mohammed Mosleh Shwaish ${ }^{2}$, Mustafa Salah Hasan ${ }^{2}$ \\ ${ }^{1}$ Ministry of Education, Alanbar Education Directorate, Iraq. ${ }^{2}$ College of Vet. Med., University of Fallujah, Iraq
}

\begin{abstract}
This study was aimed to isolate MRSA from water supplies from different places in alanbar province, fifty water samples were cultured on nutrient, macConkey and blood agars then subcultured on MSA and Staph 110, then gram stain and biochemical test done to confirm this bacteria. Then antibiotic susceptibility test were done on S. aureus by using different antibiotics including Methicillin, erythromycin, Doxycycline, Sulfa-trimethoprim, penicillin, chloramphenicol, ciprofloxacin.
\end{abstract}

The results showed that $12(24 \%)$ samples were diagnose as S. aureus, these were showed complete resistance to methicillin, erythromycin, Doxycycline and showed different percent for resistance to other antimicrobials that used.

In conclusion, the MRSA were isolated from drinking water in significant percentage and this strain of bacteria were showed higher resistance to antibiotics.

Key words: MRSA, drinking water, Antibiotic.

\section{Introduction}

The WHO reported that MRSA was an important pathogenic bacteria causing high infections that was initially detected in 1961 $\&$ became a main threats to the public health (1).

In a study of Chen et al. (2), they reported that above two million of MRSA infection cases around the different countries in the world producing human death. As described in the UK, above five thousands deaths each year were showed to be linked with MRSA, although in Netherlands, MRSA has been found to be causes for in excess of twenty percent of all infections for MRSA (3). In Europe, it has been reported that MRSA was responsible for above 170,000 infections each year, consistent to forty four percent from all infections linked to the health care (4).

Staphylococcus aureus is an environmentally widespread but it is found chiefly on the skin as well as mucous membranes of human and animals. Staphylococci are sometimes identified in the GIT and has been discovered in a sewage. S. aureus can become free by human direct contact with the water environments for example the pools for swimming as well as fun waters. It has been also identified in a drinking water supplies (5), there is an indication of spread through the drinking of such water. While Staph. Spp. are somewhat resist to residuals chlorine than the E. coli, their occurrence in water is restricted by conventional therapy as well as disinfection procedures (6).
This study aimed to isolate MRSA from human water supplies and detection of resistance to different antimicrobials by using antimicrobials sensitivity test.

\section{Materials and Method}

A Fifty drinking water specimens were taken from a different places found in Al-anbar province (Fallujah, Heet, Ramadi, Ana, Rawa, Al-qaim, Saqlawya, Garma), these were cultured on primary media (nutrient, macConkey, blood agars), then were subcultured on other media such as mannitol salt agar and Staph 110, then gram stain as well as biochemical tests were done including catalase, oxidase as well as coagulase (7).

The antibiotics sensitivity test were done according to Bauer et al. (8) by using different antibiotics including Methicillin, erythromycin, Doxycycline, Sulfa-trimethoprim, penicillin, chloramphenicol, ciprofloxacin.

\section{Results and Discussion}

The current results were showed detection of 12 isolates of MRSA from water specimens (Table 1, Fig. 1\&2).
Corresponding author:

Mustafa Salah Hasan

drmustafasalah7@gmail.com 
Table 1- Number and percentages of MRSA from different location

\begin{tabular}{|l|l|l|}
\hline Location & $\begin{array}{l}\text { Number of } \\
\text { MRSA }\end{array}$ & Percentage (\%) \\
\hline Fallujah & 1 & 8.33 \\
\hline Ramadi & 2 & 16.66 \\
\hline Heet & 1 & 8.33 \\
\hline Ana & 1 & 8.33 \\
\hline Rawa & 0 & 0 \\
\hline Al-qaim & 1 & 8.33 \\
\hline Saqlawya & 4 & 33.33 \\
\hline Garma & 2 & 16.66 \\
\hline Total & 12 & $24 \%$ \\
\hline
\end{tabular}

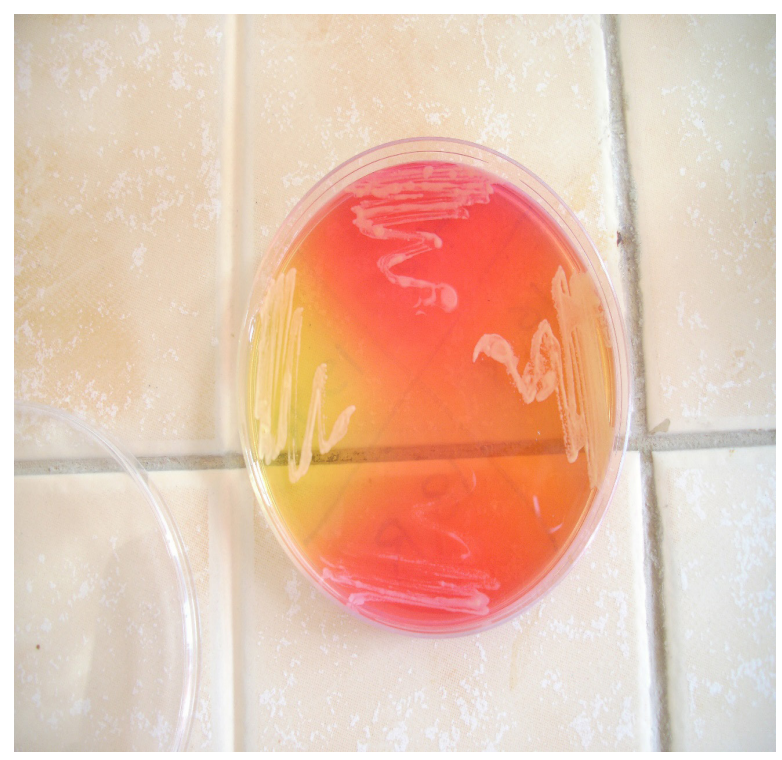

Figure -1- S. aureus on MSA (left)

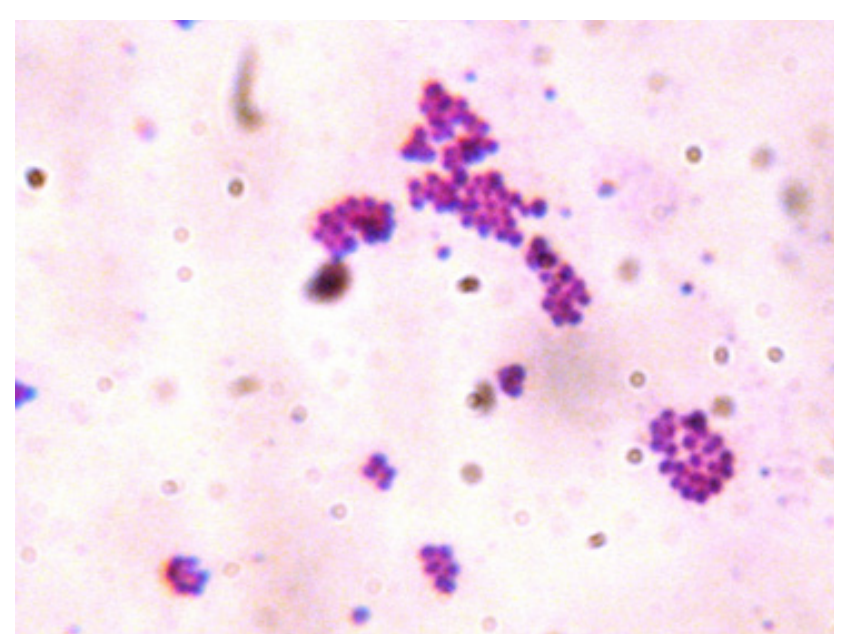

Figure -2- Gram positive cocci
The WHO reported that above $80 \%$ of all illness as well as the diseases on the world is made by insufficient hygiene, contaminated water or unreachability of water \& at least five million deaths occur in each year which attributed to the waterborne illnesses (9). These results were in agreement with results of (10) who isolated S. aureus from the water provisions. Also, these similar to results of another study in gana that showed S. aureus was detected from about $64 \%$ of the specimens, with about $34.38 \%$ from well water supplies, $32.81 \%$ from hole supply \& $31.25 \%$ from the tap water (11).

A study of Salim et al. (12) in Iraq found that Staphylocossus aureus were isolated from bottled drinking water during storage for one year at 18c. Also, in Nigeria (13) isolated $S$. aureus from a drinking water. Moreover the bacteria that resist antibiotic were upper in the tap water than in treated water (14). Additional studies have also recognized $S$. aureus that are MDR in seaside societies in their tap water as well as fresh water (15).

The results were disagree with a results of Hillo (16) who reported that $S$. aureus not detected in drinking water in Albasrah city.

The present results of antimicrobial sensitivity test for presumptive $S$. aureus (12 isolates) showed complete resistance to methicillin, erythromycin, Doxycycline and showed different percent for resistance to other antimicrobials that used (Table 2, Figure 3).

Table 2 Antimicrobial susceptibility test for $S$. aureus

\begin{tabular}{|l|l|l|}
\hline Antimicrobials & $\begin{array}{l}\text { Resistance } \\
\mathbf{( \% )}\end{array}$ & Sensitive (\%) \\
\hline Methicillin & $12(100)$ & 0 \\
\hline erythromycin & $12(100)$ & 0 \\
\hline Doxycycline & $12(100)$ & 0 \\
\hline Sulfa-trimethoprim & $5(41.7)$ & $7(58.3)$ \\
\hline penicillin & $10(83.3)$ & $2(16.7)$ \\
\hline chloroamphenicol & $3(25)$ & $9(75)$ \\
\hline ciprofloxacin & $4(33.3)$ & $8(66.7)$ \\
\hline
\end{tabular}




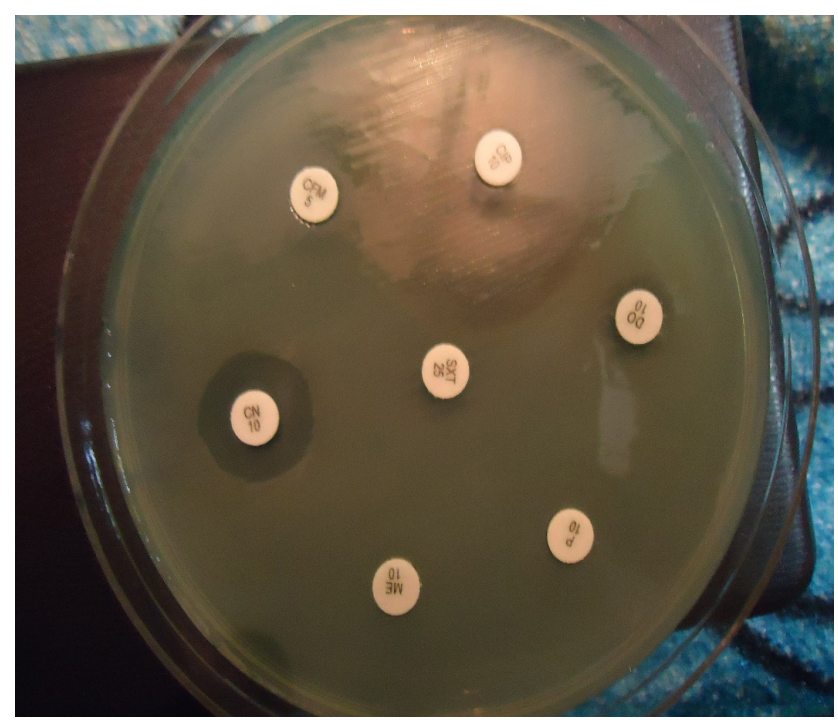

Figure 3- showing MRSA on Muller hinton agar

The current results were in agreement with results of many studies, Younis et al. (17) reported that $96.6 \%$ of $S$. aureus isolates were resistant to penicillin. Shi et al. (18) reported that $87.6 \%$ of isolates were resist to penicillin. Abera et al. (19) recorded that $94.4 \%$ of isolates were resist to the penicillin. Vanderhaeghen et al. (20) reported that all isolates (118 S. aureus isolates) in their study were resist to tetracycline. Tiao (21) found that none of the $20 \mathrm{~S}$. aureus isolates tested in her study carried the mecA gene and one showed methicillin resistance phenotypically. Turutoglu et al. (22) stated that out of $18 \mathrm{~S}$. aureus isolates, 15 were typically resist to the methicillin but didn't carry the mecA gene.

Also, this strains presented greater amounts of resistance to the family of macrolides especially erythromycin as reported by (23).

The incidence of genes that responsible to antibiotic resistant in a drinking water is of special concern because of the amount of persons as well as animals who possibly affected by consuming contaminated water that comprising the bacteria which were antibiotic resistant that can transmit antibiotic resistance to the usual bacterial flora in the bowels of human as well as animals.

The presence of resistance for most antibiotics that used may be due to random usage of antibiotics and usage of drugs by incomplete course, these may lead to what is called multi drug resistance bacteria.

It has been concluded that MRSA isolated from water supplier in a significant number and this has been resist to multiple antibiotics.
Ethical Clearance: The Research Ethical Committee at scientific research by ethical approval of both environmental and health and higher education and scientific research ministries in Iraq

Conflict of Interest: The authors declare that they have no conflict of interest.

Funding: Self-funding

\section{References}

1. Hartman BJ \& Tomasz A. Expression of methicillin resistance in heterogeneous strains of Staphylococcus aureus. Antimicrobial Agents and Chemotherapy, 1986; 29(1): 85-92.)

2. Chen SY, Liao C H, Wang JL, Chiang WC, Lai M S, Chie WC \& Hsueh PR. Methicillin-resistant Staphylococcus aureus (MRSA) staphylococcal cassette chromosome mec genotype effects outcomes of patients with healthcare-associated MRSA bacteremia independently of vancomycin minimum inhibitory concentration. Clinical infectious diseases, 2012; 55(10): 1329-1337.

3. Van Loo I, Huijsdens X, Tiemersma E, De Neeling A, van de Sande-Bruinsma N, Beaujean D \& Kluytmans J. Emergence of methicillin-resistant Staphylococcus aureus of animal origin in humans. Emerging infectious diseases, 2007; 13(12): 1834 .

4. ECDC E. The bacterial challenge: time to react. Stockholm: European Center for Disease Prevention and Control, 2009.

5. Antai SP. Incidence of Staphylococcus aureus, coliforms and antibiotic $\square$ resistant strains of Escherichia coli in rural water supplies in Port Harcourt. Journal of Applied Bacteriology, 1987; 62(4): 371-375.

6. LeChevallier MW \& Seidler RJ. Staphylococcus aureus in rural drinking water. Appl. Environ. Microbiol., 1980; 39(4): 739-742.)

7. Markey B, Leonard F, Archambault M, Cullinane A \& Maguire D. Clinical veterinary microbiology e-book. Elsevier Health Sciences, 2013: 119.

8. Bauer AW, Kirby WMM, Sherris JC \& Turck M. Antibiotic susceptibility testing by a standardized single disk method. American journal of clinical pathology, 1966; 45(4_ts): 493-496.

9. Karn SK \& Harada H. Surface water pollution in three urban territories of Nepal, India, and Bangladesh. Environmental Management, 2001; 
28(4): 483-496?

10. Hill RD, Schwab GO, Malaney GW \& Weiser HH. Quality of Water in Ohio Farm Ponds, Ohio Agr. Exp. Sta. Research Bulletin, 1962: 922.

11. Osei F B, Boamah VE, Agyare C \& Abaidoo R C. Physicochemical Properties and Microbial Quality of Water Used in Selected Poultry Farms in the Ashanti Region of Ghana. The Open Microbiology Journal,2019; 13(1).

12. Abdullah S M. BACTERIAL AND CHEMICAL CONTAMINATION OF SOME DRINKING WATER IN BASRAH. journal of al-qadisiyah for pure science (quarterly), 2006; 11(3), 78-88.

13. Shittu O B, Olaitan JO \& Amusa T S. Physicochemical and bacteriological analyses of water used for drinking and swimming purposes in abeokuta, nigeria. African Journal of Biomedical Research, 2008; 11(3)!

14. Xi C, Zhang Y, Marrs C F, Ye W, Simon C, Foxman B \& Nriagu J. Prevalence of antibiotic resistance in drinking water treatment and distribution systems. Appl. Environ. Microbiol., 2009; 75(17): 57145718.

15. Harakeh S, Yassine $\mathrm{H}$, Hajjar $\mathrm{S} \&$ El-Fadel M. Isolates of Staphylococcus aureus and saprophyticus resistant to antimicrobials isolated from the Lebanese aquatic environment. Marine pollution bulletin, 2006; 52(8): 912-919.

16. Hillo NA. Bacteriological Assessment of some domestic bottled waters marketed in Basrah governorate, Iraq. MARSH BULLETIN, 2016; 11 ( 2 ): 125-134.

17. Younis A, Leitner G, Heller D E, Samra Z, Gadba R, Lubashevsky G \& Saran A. Phenotypic characteristics of Staphylococcus aureus isolated from bovine mastitis in Israeli dairy herds. Journal of Veterinary Medicine, Series B, 2000; 47(8): 591-597.

18. Shi D, Hao Y, Zhang A, Wulan B \& Fan X. Antimicrobial resistance of Staphylococcus aureus isolated from bovine mastitis in China. Transboundary and emerging diseases, 2010; 57(4): 221-224.

19. Abera M, Demie B, Aragaw K, Regassa, F \& Regassa A. Isolation and identification of Staphylococcus aureus from bovine mastitic milk and their drug resistance patterns in Adama town, Ethiopia. Journal of Veterinary Medicine and Animal Health, 2010; 2(3): 29-34.

20. Vanderhaeghen W, Cerpentier T, Adriaensen C, Vicca J, Hermans K \& Butaye P. Methicillinresistant Staphylococcus aureus (MRSA) ST398 associated with clinical and subclinical mastitis in Belgian cows. Veterinary microbiology, 2010; 144(1-2):166-171.

21. Tiao N. Phenotypic and Genotypic Characterization of Staphylococci from Dairy in Northeast Brazil, MS thesis, The Ohio State University, 2008.

22. Turutoglu H, Hasoksuz M, Ozturk D, Yildirim M \& Sagnak S. Methicillin and aminoglycoside resistance in Staphylococcus aureus isolates from bovine mastitis and sequence analysis of their mecA genes. Veterinary research communications, 2009; 33(8): 945-956.

23. Rajaduraipandi K, Mani KR, Panneerselvam K, Mani M, Bhaskar M \& Manikandan P. Prevalence and antimicrobial susceptibility pattern of methicillin resistant Staphylococcus aureus: A multicentre study. Indian journal of medical microbiology, 2006; 24(1): 34. 